\title{
Diagnosis and Treatment Outcome of Mycotic Keratitis at a Tertiary Eye Care Center in Eastern India
}

Bibhudutta Rautaraya ${ }^{1 *}$, Savitri Sharma ${ }^{1}$, Sarita Kar ${ }^{1}$, Sujata Das ${ }^{2}$ and Srikant K Sahu²

\begin{abstract}
Background: Mycotic keratitis is an important cause of corneal blindness world over including India. Geographical location and climate are known to influence the profile of fungal diseases. While there are several reports on mycotic keratitis from southern India, comprehensive clinico-microbiological reports from eastern India are few. The reported prevalence of mycotic keratitis are 36.7\%,36.3\%,25.6\%,7.3\% in southern, western, north- eastern and northern India respectively. This study reports the epidemiological characteristics, microbiological diagnosis and treatment outcome of mycotic keratitis at a tertiary eye care center in eastern India.

Methods: A retrospective review of medical and microbiology records was done for all patients with laboratory proven fungal keratitis.

Results: Between July 2006 and December 2009, 997 patients were clinically diagnosed as microbial keratitis. While no organisms were found in 25.4\% (253/997) corneal samples, 23.4\% (233/997) were bacterial, 26.4\% (264/997) were fungal (45 cases mixed with bacteria), 1.4\% (14/997) were Acanthamoeba with or without bacteria and 23.4\% (233/997) were microsporidial with or without bacteria. Two hundred fifteen of 264 (81.4\%, 215/264) samples grew fungus in culture while 49 corneal scrapings were positive for fungal elements only in direct microscopy. Clinical diagnosis of fungal keratitis was made in 186 of 264 (70.5\%) cases. The microscopic detection of fungal elements was achieved by $10 \%$ potassium hydroxide with $0.1 \%$ calcoflour white stain in $94.8 \%(238 / 251)$ cases. Aspergillus species $(27.9 \%, 60 / 215)$ and Fusarium species $(23.2 \%, 50 / 215)$ were the major fungal isolates. Concomitant bacterial infection was seen in $45(17.1 \%, 45 / 264)$ cases of mycotic keratitis. Clinical outcome of healed scar was achieved in 94 (35.6\%, 94/264) cases. Fifty two patients (19.7\%, 52/264) required therapeutic PK, 9 (3.4\%, 9/264) went for evisceration, 18.9\% (50/264) received glue application with bandage contact lens (BCL) for impending perforation, 6.1\% (16/264) were unchanged and 16.3\% (43/264) were lost to follow up. Poor prognosis like PK (40/52, 75.9\%, $\mathrm{p}<0.001)$ and $\mathrm{BCL}(30 / 50,60 \%, \mathrm{p}<0.001)$ was seen in significantly larger number of patients with late presentation (> 10 days).

Conclusions: The relative prevalence of mycotic keratitis in eastern India is lower than southern, western and north-eastern India but higher than northern India, however, Aspergillus and Fusarium are the predominant genera associated with fungal keratitis across India. The response to medical treatment is poor in patients with late presentation.
\end{abstract}

Keywords: Mycotic, fungal, keratitis, microscopy, culture, treatment outcome

\footnotetext{
* Correspondence: drbibhu_75@rediffmail.com

'Ocular Microbiology Service, L. V. Prasad Eye Institute, Bhubaneswar-751024,

Odisha, India

Full list of author information is available at the end of the article
}

\section{Ciomed Central}

(c) 2011 Rautaraya et al; licensee BioMed Central Ltd. This is an Open Access article distributed under the terms of the Creative Commons Attribution License (http://creativecommons.org/licenses/by/2.0), which permits unrestricted use, distribution, and reproduction in any medium, provided the original work is properly cited. 


\section{Background}

Corneal blindness is a major public health problem worldwide and infectious keratitis is one of the predominant causes. Certain conditions like trauma to the eyeball and therapy with antibiotics and corticosteroids render the eye susceptible to infection with various fungi especially in tropical parts of the world [1]. A large number of studies from India have reported epidemiological and microbiological profile of fungal keratitis [1-8], however, there are only few that have provided a comprehensive analysis of the clinical and laboratory profile [5,7]. Minor differences in the frequency and spectrum of fungi associated with mycotic keratitis have been reported from southern (36.7\%) [2] northern (7.3\%) [4] western (36.3\%) [6] and north-eastern (25.6\%) [7] India. Both the studies from northeastern India have reported high prevalence $(38 \%$ and $42 \%$ ) of fungal keratitis in the region $[7,8]$. Knowledge of these differences coupled with their corresponding epidemiological features, clinical features and treatment outcome is likely to help the ophthalmologists manage this challenging disease in their area. Comprehensive periodic reports from different geographical areas would help record the variations over a period of time and at the same time provide current diagnostic and management strategies with the possible outcome.

This study presents the wide-ranging clinical and microbiological analysis of 264 cases of mycotic keratitis seen over three and half years period at a tertiary eye care centre in eastern India where all patients were investigated and treated with a uniform protocol.

\section{Methods}

A retrospective analysis was performed for all patients seen between July 2006 and December 2009 with laboratoryproven fungal keratitis. This study was approved by institutional review board of L V Prasad Eye Institute (Ethics Ref. No. LEC 11-071). Documentation of all patients included socio-demographic features, duration of symptoms, predisposing factors, slit lamp biomicroscopy findings, associated ocular conditions, other systemic diseases, therapy received prior to presentation, visual acuity at the time of presentation, treatment given, response to treatment during follow up and the clinical outcome. Based on duration of symptoms the patients were divided in to early onset ( $\leq 10$ days) or late onset ( $>10$ days) disease.

Corneal scrapings were collected and processed from all patients as per the institutional protocol published earlier [5]. Multiple scrapings were collected from each patient for microscopy and culture. Numbers of scrapings collected for direct microscopic examination varied from 1-3. Whenever three scrapings were taken, they tended to be sequentially collected and respectively stained by $10 \%$ potassium hydroxide with $0.1 \%$ calcofluor white ( $\mathrm{KOH}+\mathrm{CFW}$, fluorescence microscopy), Gram and Giemsa stains. The criteria to determine significance of a culture included (i) confluent growth in any solid media; and/or (ii) growth in more than one medium; and/or (iii) growth in one medium with presence of the organism in direct microscopy; and/or (iv) repeat isolation of the organism. For patients undergoing keratoplasty, the corneal tissue removed at keratoplasty was bisected across the ulcer and half of it was submitted to microbiology laboratory in a sterile container. The tissue was minced aseptically using sterile blade and the fragments were inoculated on sheep blood/chocolate agar, brain heart infusion broth, thioglycollate broth and Sabouraud dextrose agar with chloramphenicol. The media were incubated and interpreted as for corneal scrapings [5].

Antifungal topical therapy with 5\% natamycin was started for all cases immediately on receiving a positive report of fungal filaments by microscopic examination of the corneal scraping. One hourly topical drops were applied for first three days round the clock followed by two hourly drops during waking hours until resolution of the ulcers. Patients also received 1\% atropine sulphate drops. During the study period, under a randomized control study, 6/264 (2.2\%) patients had been treated with $1.25 \%$ povidone iodine in the same dosage. Systemic ketoconazole (200 mg twice daily) or itraconazole $(100 \mathrm{mg}$ twice daily) or fluconazole (150 mg once a day) was prescribed to 158 (58.3\%) patients with corneal stromal infiltrate extending beyond one third of the cornea. Additional procedures at the discretion of the clinicians were undertaken for patients not responding to medical therapy and they included therapeutic penetrating keratoplasty (PK), evisceration, and cyanoacrylate glue application with bandage contact lens or anterior chamber wash with amphotericin B.

Post-treatment, an ulcer was considered healed when the epithelial defect was found to be $<1 \mathrm{~mm}$ in maximum diameter with slit lamp biomicroscopy and a visible scar. A healing time of $<3$ weeks from presentation was considered good result and healing time more than three weeks was considered a poor response.

\section{Results}

During the study period 997 patients were clinically diagnosed as microbial keratitis and were investigated for bacteria, fungi or parasites. While no organisms were found in $253(25.3 \%)$ clinical samples, $233(23.4 \%)$ were bacterial, 264 (26.4\%) were fungal with or without bacteria, 10 (1\%) were Acanthamoeba and 221 (22.16\%) were microsporidia. Sixteen patients (1.6\%) had parasitic infection mixed with bacteria (Acanthamoeba + bacteria-4, Microsporidia + bacteria -12). Of the 264 patients with fungal keratitis the diagnosis was made by examination of corneal scrapings 
in $221(83.71 \%)$, corneal tissue in 7 (2.65\%) and both corneal scraping and corneal tissue in $36(13.6 \%)$ patients. Two hundred fifteen of 264 (81.4\%) samples grew fungus in culture while 49 corneal scrapings were positive for fungal elements only in direct microscopy and culture were negative. Among the 215 culture positive cases, the growth in culture was considered significant based on confluent growth in 19 cases and based on growth in two or more media in two cases. In 194 cases the smear was positive and culture showed growth in one or more media. In no case repeat culture was required for determining significance of the culture. Clinical diagnosis in the 264 mycotic keratitis varied from fungal in 186 (70.45\%), bacterial in 25 (9.4\%), viral in $4(1.5 \%)$, Acanthamoeba in $1(0.4 \%)$ and indeterminate microbial keratitis in 48 (18.2\%). Figure 1 shows the results of three methods used for direct microscopy of corneal scrapings. While 251 corneal scrapings were examined by $\mathrm{KOH}+\mathrm{CFW}, 252$ had been examined by Gram stain and 105 had been examined by Giemsa stain. Detection of fungal elements in corneal scrapings was $94.8 \%$ by $\mathrm{KOH}+\mathrm{CFW}$ stain. In culture, Aspergillus species (27.9\%) and Fusarium species (23.2\%) were the major isolates (Table 1). Of the 215 fungal isolates 172 were from corneal scrapings, 7 were from corneal tissue and 36 were from both corneal scraping and corneal tissue. Age and gender distribution of the patients is shown in Table 2, which shows higher prevalence of mycotic keratitis in males $185(70 \%)$. Concomitant bacterial infection was seen in 45 (17.1\%) cases of mycotic keratitis and Staphylococcus species $(14,31.1 \%)$ was the predominant bacterial pathogen (Table 3). The data pertaining to predisposing factor was not available in 149 (56.4\%) patients. Seventy-five $(28.4 \%)$ patients were farmers. Corneal trauma in 106 (40.15\%) patients was identified as the predominant predisposing factor while $6(2.2 \%)$ patients had diabetes and $3(1.1 \%)$ had both.

Treatment outcome of the patients is shown in Table 4 . While 43 (16.28\%) patients were lost to follow up (before 4 weeks), the clinical outcome of healed scar was achieved in 94. (35.6\%) cases. Twenty nine out of 94 patients (30.9\%) had healed scars in $<3$ weeks from the date of presentation. Fifty two patients (19.7\%) required therapeutic PK, 50 patients required tissue adhesive with bandage contact lens and 9 (3.4\%) went for evisceration. In 16 patients there was no change in ulcer at the time of data collection. The mean follow up of the patients was $43 \pm 115$ days. Analysis of treatment outcome in patients seen before 10 days (early) and after 10 days (late) of presentation showed a significantly $(\mathrm{p}<0.001)$ higher surgical intervention (PK and tissue adhesive) in late cases (Table 4).

\section{Discussion}

This study presents a thorough laboratory and clinical data of a large number of mycotic keratitis patients from eastern India. A comparison of the results with recent data from other parts of the country is shown in Table 5. Fairly large numbers of patients have been analyzed in all of these hospital based published reports. While the prevalence recorded from the southern, western and north-eastern India is between $21-37 \%$, it is only $7.3 \%$ from Chandigarh. In a larger study of 3528 microbial keratitis cases in Delhi (north India), the prevalence of fungal keratitis was reported to be $24.3 \%$ [9]. Across the country, mycotic keratitis seems to be prevalent in males, in farmers and the most common predisposing factor remains trauma to the cornea. The predominant age is young adults in most studies [2,6] however, some studies [4,7] including the present one find higher prevalence in males between 50-60 years of age.

In the hands of experienced cornea specialists the clinical acumen to make a diagnosis of mycotic keratitis varies in different studies from 71-100\% [2]. Nevertheless, in all studies, the diagnosis of fungal keratitis is remarkably efficient using relatively simple methods such as potassium hydroxide wet mount and Gram stain. In this study, at $94.8 \%$, the detection of fungal elements in corneal scrapings was very high by microscopy using $\mathrm{KOH}+\mathrm{CFW}$ stain. Being a retrospective study we are aware that this favorable result could be biased as the first scraping was invariably taken for $\mathrm{KOH}+\mathrm{CFW}$ stain, especially in cases where clinical suspicion of fungal keratitis was high. However, as supported by several studies $[10,11]$ calcofluor white is indeed a highly reliable and sensitive stain for fungal detection under fluorescence microscope. Since, clinical acumen would vary according to the level of training and experience, it seems appropriate for all practitioners to have the minimum laboratory facility available in their clinic for the management of microbial keratitis. When attempted, it is fairly easy to grow and identify fungi from corneal scrapings and the most common fungi isolated are either Fusarium or Aspergillus spp [2,4,6,7]. The source of these fungi is obviously the environment which is rife with similar species of fungi [12]. Candida spp. are uncommon causes of mycotic keratitis in almost all studies including the present study, though Saha et al have recorded a prevalence of $19 \%$ [7]. Only a community based study could show the true prevalence of fungal keratitis. Under the pyramidal model of eye care, currently, L V Prasad Eye Institute is committed to support laboratory facilities in all its secondary centers and provide the minimum requirement of a microscope with potassium hydroxide and Gram stain to examine corneal scrapings from all patients with microbial keratitis. A similar approach at a large scale is recommended.

To determine type of fungi one would require culture facilities in the laboratory. In addition, culture of the corneal scrapings or corneal tissue is the only way to 


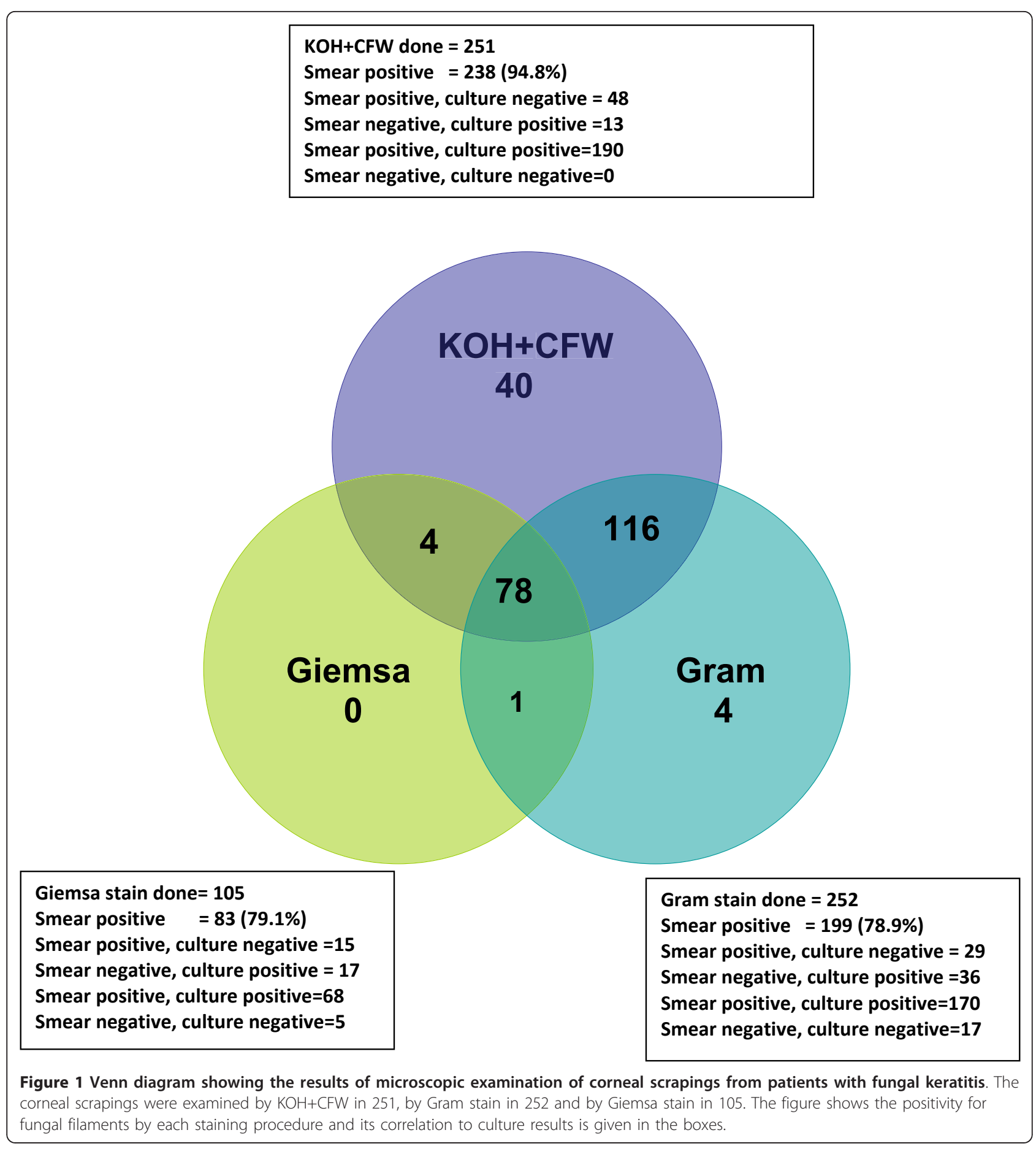

determine mixed fungal and bacterial infections which require combined treatment with antifungal and antibacterial antibiotics. The prevalence of mixed infection varies from $6-10 \%[2,6]$ however, this study found $17 \%$ patients with mixed infection. While Deshpande et al [6] found Pseudomonas aeruginosa as the most common bacteria in mixed infections the commonest organism in this study was Staphylococcus spp. Presence of
Pseudomonas spp. is of particular significance especially in face of the finding of contaminated natamycin eye drops [13]. Treating ophthalmologists would be well advised to take a repeat corneal scraping for culture from a fungal ulcer not responding to treatment, to rule out contamination with Pseudomonas spp.

Treatment outcome in mycotic keratitis remains less than satisfactory in most reports $[5,7]$ and this study is no 
Table 1 Distribution of various fungal species in patients with mycotic keratitis $(n=215)$

\begin{tabular}{|c|c|c|c|}
\hline Type of fungus & Fungal isolates & Number & $\begin{array}{c}\text { Percentage } \\
(\%)\end{array}$ \\
\hline \multirow[t]{15}{*}{ Hyaline fungi } & A. flavus & 34 & 15.8 \\
\hline & A. fumigatus & 14 & 6.5 \\
\hline & Other Aspergillus spp. & 12 & 5.8 \\
\hline & F. solani & 23 & 10.7 \\
\hline & Other Fusarium spp. & 27 & 12.6 \\
\hline & Acremonium spp. & 10 & 4.7 \\
\hline & Colletotrichum spp. & 3 & 1.4 \\
\hline & Trichosporon spp. & 2 & 0.9 \\
\hline & Penicillium spp. & 2 & 0.9 \\
\hline & Paecilomyces sp. & 1 & 0.5 \\
\hline & Scedosporium apiospermum & 6 & 2.7 \\
\hline & Aureobasidium pullulans & 1 & 0.5 \\
\hline & Sepedonium sp. & 1 & 0.1 \\
\hline & Phialophora verrucosa & 1 & 0.5 \\
\hline & Unidentified hyaline fungus & 20 & 9.3 \\
\hline \multirow[t]{10}{*}{ Dematiaceous fungi } & Curvularia lunata & 6 & 2.7 \\
\hline & Other Curvularia spp. & 2 & 0.9 \\
\hline & Cladosporium spp. & 3 & 1.4 \\
\hline & Lasiodiplodia theobromae & 2 & 0.9 \\
\hline & Nigrospora spp. & 2 & 0.9 \\
\hline & Bipolaris spicifera & 2 & 0.9 \\
\hline & Exophiala spp. & 2 & 0.9 \\
\hline & Alternaria alternata & 1 & 0.5 \\
\hline & Cladophialophora sp. & 1 & 0.5 \\
\hline & Unidentified dematiaceous fungus & 34 & 15.8 \\
\hline \multirow[t]{2}{*}{ Yeast } & Candida spp. & 2 & 0.9 \\
\hline & Rhodotorula glutinis & 1 & 0.5 \\
\hline
\end{tabular}

exception. Fifty two patients (19.7\%) required therapeutic PK and 9 (3.4\%) went for evisceration. Saha et al reported PK in $60 \%$ of their patients. A large number of patients

Table 2 Age and gender distribution of patients with mycotic keratitis $(n=264)$

\begin{tabular}{cccc}
\hline Age in years & $\begin{array}{c}\text { Male } \\
\text { No. (\%) }\end{array}$ & $\begin{array}{c}\text { Female } \\
\text { No. (\%) }\end{array}$ & $\begin{array}{c}\text { Total } \\
\text { No. (\%) }\end{array}$ \\
\hline $0-9$ & $3(1.6)$ & 0 & $3(1.1)$ \\
\hline $10-19$ & $4(1.2)$ & $4(5)$ & $8(3)$ \\
\hline $20-29$ & $23(12.4)$ & $2(2.5)$ & $25(9.5)$ \\
\hline $30-39$ & $33(17.8)$ & $11(13.9)$ & $44(16.7)$ \\
\hline $40-49$ & $41(22.2)$ & $18(22.7)$ & $59(22.3)$ \\
\hline $50-59$ & $38(20.5)$ & $24(30.4)$ & $62(23.5)$ \\
\hline $60-69$ & $27(14.6)$ & $11(13.9)$ & $38(14.4)$ \\
\hline $70-79$ & $14(7.6)$ & $6(7.6)$ & $20(7.6)$ \\
\hline 80 and above & $2(1.1)$ & $3(3.8)$ & $5(1.9)$ \\
\hline Total & $185(70.1)$ & $79(29.9)$ & $264(100)$ \\
\hline
\end{tabular}

require therapeutic keratoplasty (PK) despite full treatment with natamycin. Expectedly, early treatment results in favorable outcome. This was obvious in this study as larger number (Table 4) of patients with poor outcome had presented later than 10 days of starting of symptoms. PK and tissue adhesive for impending perforation were seen in significantly more number of patients who presented late. Newer antifungals with greater penetration compared to natamycin have shown promising results in the treatment of mycotic keratitis [14].

\section{Conclusions}

This study highlights that the relative prevalence of mycotic keratitis is less compared to other parts of India and is higher than northern India. The predominant genera of fungi involved (Aspergillus and Fusarium) are similar across India. Unlike other studies, the prevalence is more in older age groups in this study. The study also shows that fungal keratitis can be easily diagnosed 
Table 3 Types of bacteria isolated along with fungi in mixed fungal infections $(n=45)$

\begin{tabular}{|c|c|c|c|}
\hline SI No. & Bacterial isolates & Number & Percentage (\%) \\
\hline 1 & Staphylococcus species & 14 & 31.1 \\
\hline 2 & Staphylococcus aureus & 3 & 6.6 \\
\hline 3 & Corynebacterium species & 6 & 12.7 \\
\hline 4 & Pseudomonas aeruginosa & 3 & 6.6 \\
\hline 5 & Pseudomonas species & 2 & 4.4 \\
\hline 6 & Pseudomonas species + Staphylococcus aureus & 3 & 6.6 \\
\hline 7 & Pseudomonas aeruginosa + Micrococcus species & 1 & 2.2 \\
\hline 8 & Corynebacterium species +Streptococcus pneumoniae & 2 & 4.4 \\
\hline 9 & Corynebacterium species +Klebsiella species & 1 & 2.2 \\
\hline 10 & Staphylococcus aureus +Corynebacterium species & 2 & 4.4 \\
\hline 11 & Streptococcus pneumoniae & 4 & 8.5 \\
\hline 12 & Micrococcus species & 2 & 4.4 \\
\hline 13 & Acinetobacter species & 1 & 2.2 \\
\hline 14 & Nocardia asteroides & 1 & 2.2 \\
\hline
\end{tabular}

Table 4 Treatment outcome of patients with mycotic keratitis $(n=264)$

\begin{tabular}{|c|c|c|c|c|}
\hline \multirow[t]{2}{*}{$\begin{array}{l}\text { Treatment outcome } \\
\text { (No. of cases) }\end{array}$} & \multicolumn{3}{|c|}{$\begin{array}{l}\text { Duration of } \\
\text { presentation }\end{array}$} & \multirow[t]{2}{*}{$\begin{array}{c}\text { Duration not known } \\
\text { No. (\%) }\end{array}$} \\
\hline & $\begin{array}{c}\text { Early ( } \leq 10 \text { days) } \\
\text { No. }(\%)\end{array}$ & $\begin{array}{c}\text { Late (> } 10 \text { days) } \\
\text { No. }(\%)\end{array}$ & $P$ value & \\
\hline Healed $(n=94)$ & $45(47.8)$ & $43(45.6)$ & 0.88 & $6(6.5)$ \\
\hline Penetrating Keratoplasty $(n=52)$ & $6(12.9)$ & $40(76.9)$ & $<0.001$ & $6(11.1)$ \\
\hline Evisceration $(n=9)$ & - & $5(55.5)$ & & $4(44.4)$ \\
\hline Tissue Adhesive + Bandage Contact Lens $(n=50)$ & $12(24)$ & $30(60)$ & $<0.001$ & $8(16)$ \\
\hline Status quo $(n=16)$ & $4(25)$ & $10(62.5)$ & 0.074 & $2(12.5)$ \\
\hline
\end{tabular}

Lost to follow up- 43 (16.3\%)

Table 5 Comparison of microbiological and clinical data on fungal keratitis from studies from various parts of India Parameters Bharathi et al (South) Despande et al(West) [6] [2]

$\begin{array}{lll}\begin{array}{l}\text { Saha et al } \\ \text { (North East)[7] }\end{array} & \begin{array}{l}\text { Chander \& } \\ \text { Sharma } \\ \text { (North)[4] }\end{array} & \begin{array}{l}\text { Prese } \\ \text { (East) }\end{array} \\ & & \end{array}$

\begin{tabular}{|c|c|c|c|c|c|}
\hline \multicolumn{6}{|l|}{ General } \\
\hline Type of study & Retrospective & Prospective & Retrospective & Prospective & Retrospective \\
\hline Period of study & Sep1999-Aug2002 & 1988-1996 & 2008 & Jan1987-Dec1992 & July2006-Dec2009 \\
\hline Duration & 3 years & 9 years & 1 year & 6 years & 3.5 years \\
\hline $\begin{array}{l}\text { No. of patients with microbial } \\
\text { keratitis }\end{array}$ & 3183 & 1010 & 289 & 730 & 997 \\
\hline \multicolumn{6}{|l|}{ Microbiology } \\
\hline Culture positive for fungus & $1171(36.7 \%)$ & $367(36.3 \%)$ & $74(25.6 \%)$ & $53(7.3 \%)$ & $215(21.5 \%)$ \\
\hline \multicolumn{6}{|c|}{ Nature of sample from which fungus isolated } \\
\hline Corneal scraping & $1171 / 1171(100 \%)$ & $367 / 367(100 \%)$ & $41 / 74(55.4 \%)$ & NM & $172 / 215(80.0 \%)$ \\
\hline Corneal tissue & NM & NM & $16 / 74(21.6 \%)$ & NM & $7 / 215(3.2 \%)$ \\
\hline Corneal scraping and tissue & NM & NM & NM & NM & $36 / 215(16.7 \%)$ \\
\hline \multicolumn{6}{|c|}{ Analysis of wet mount and different staining methods } \\
\hline $\begin{array}{l}\mathrm{KOH} / \mathrm{CFW} \\
\text { positive }\end{array}$ & $\begin{array}{l}1181 / 1181 \\
(100 \%)\end{array}$ & $367(36.3 \%)$ & $110(38.06 \%)$ & NM & 238/251(94.8\%) \\
\hline $\begin{array}{l}\text { Gram } \\
\text { positive }\end{array}$ & $\begin{array}{l}1039 / 1181 \\
(87.9 \%)\end{array}$ & $347(34.4 \%)$ & NM & NM & 199/252(78.9\%) \\
\hline $\begin{array}{l}\text { Giemsa } \\
\text { Positive }\end{array}$ & NM & NM & NM & NM & $83 / 105(79.0 \%)$ \\
\hline
\end{tabular}


Table 5 Comparison of microbiological and clinical data on fungal keratitis from studies from various parts of India (Continued)

\begin{tabular}{|c|c|c|c|c|c|}
\hline $\begin{array}{l}\text { Smear positive } \\
\text { Culture negative }\end{array}$ & $11 / 1181(0.9 \%)$ & 0 & $36 / 289(12.4 \%)$ & NM & $49 / 257(19.0 \%)$ \\
\hline $\begin{array}{l}\text { Fungal culture } \\
\text { Positive }\end{array}$ & $1095 / 1181(92.7) \%$ & $36.3 \%$ & $74 / 110(67.2 \%)$ & $7.3 \%$ & $215 / 264(81.4 \%)$ \\
\hline $\begin{array}{l}\text { Most common } \\
\text { Fungal isolate }\end{array}$ & Fusarium spp. (43\%) & $\begin{array}{l}\text { Aspergillus } \\
\text { spp. (67.8\%) }\end{array}$ & $\begin{array}{l}\text { Aspergillus } \\
\text { spp. (55\%) }\end{array}$ & $\begin{array}{l}\text { Aspergillus } \\
\text { spp. (40\%) }\end{array}$ & $\begin{array}{l}\text { Aspergillus } \\
\text { spp. (28\%) }\end{array}$ \\
\hline $2^{\text {nd }}$ common isolate & $\begin{array}{l}\text { Aspergillus } \\
\text { spp. (26\%) }\end{array}$ & Candida spp. (9.8\%) & $\begin{array}{l}\text { Candida spp. } \\
(19 \%)\end{array}$ & $\begin{array}{l}\text { Fusarium spp. } \\
(16.4 \%)\end{array}$ & $\begin{array}{l}\text { Fusarium spp. } \\
(23 \%)\end{array}$ \\
\hline \multicolumn{6}{|l|}{ Concomitant infection } \\
\hline Mixed with bacteria & 76/1181(6.4\%) & $40 / 367(10.8 \%)$ & NM & NM & $17 \%$ \\
\hline $\begin{array}{l}\text { Most common } \\
\text { Bacterial isolate }\end{array}$ & NM & $\begin{array}{l}\text { Pseudomonas aeruginosa } \\
(66 \%)\end{array}$ & NM & NM & $\begin{array}{l}\text { Staphylococcus } \\
\text { spp. (31\%) }\end{array}$ \\
\hline \multicolumn{6}{|l|}{ Clinical aspect } \\
\hline Age Range & $31-40(24 \%)$ & $31-40$ & $50-60$ & $51-60$ & $50-60(63 \%)$ \\
\hline Gender & Male (65\%) & Male & Male & Male & Male (70\%) \\
\hline $\begin{array}{l}\text { Residence } \\
\text { Rural }\end{array}$ & $80.3 \%$ & NM & NM & NM & $79.5 \%$ \\
\hline Urban & $20 \%$ & & & & $21 \%$ \\
\hline $\begin{array}{l}\text { Most common predisposing } \\
\text { factor }\end{array}$ & Trauma (92\%) & Trauma (55\%) & Trauma (48\%) & NM & Trauma (40\%) \\
\hline Occupation & Farmer (65\%) & NM & NM & NM & Farmer (28\%) \\
\hline \multicolumn{6}{|l|}{ Clinical Diagnosis } \\
\hline Fungal keratitis & $94.1 \%$ & $100 \%$ & NM & NM & $71 \%$ \\
\hline Bacterial keratitis & NM & NM & NM & NM & $9 \%$ \\
\hline Viral keratitis & NM & NM & NM & NM & $1.5 \%$ \\
\hline Acanthoemba keratitis & NM & NM & NM & NM & $0.4 \%$ \\
\hline \multicolumn{6}{|l|}{ Treatment given } \\
\hline Topical natamycin or voriconazole & NM & NM & $100 \%$ & NM & $94.3 \%$ \\
\hline Systemic ketoconazole & NM & NM & $100 \%$ & NM & $60 \%$ \\
\hline Therapeutic PK & NM & NM & $60 \%$ & NM & $21 \%$ \\
\hline Evisceration & NM & NM & NM & NM & $3.4 \%$ \\
\hline \multicolumn{6}{|l|}{ Treatment outcome } \\
\hline Scar & NM & NM & $40 \%$ & NM & $35 \%$ \\
\hline $\begin{array}{l}\text { Healing time } \\
<3 \text { weeks }\end{array}$ & NM & NM & NM & NM & $32 \%$ \\
\hline $\begin{array}{l}\text { Duration of symptoms } \\
\text { Early onset } \\
<10 \text { days }\end{array}$ & NM & NM & NM & NM & $92(34.8 \%)$ \\
\hline $\begin{array}{l}\text { Late onset } \\
>10 \text { days }\end{array}$ & NM & NM & NM & NM & $172(65.2)$ \\
\hline
\end{tabular}

clinically and by laboratory methods, however it remains a therapeutic challenge to the ophthalmologists.

Acknowledgements for financial support

Hyderabad Eye Research Foundation, Hyderabad, India.

\section{Author details}

'Ocular Microbiology Service, L. V. Prasad Eye Institute, Bhubaneswar-751024,

Odisha, India. ${ }^{2}$ Cornea and Anterior Segment Service, L. V. Prasad Eye

Institute, Bhubaneswar-751024, Odisha, India.

\section{Authors' contributions}

SKS and SD clinically diagnosed the cases in the out-patient service and collected corneal scrapings for staining and culture. BD, SS and SK helped in examining the slides as well identification of the fungal isolates. They also did retrospective analysis of the data as well as statistical analysis. The manuscript was written by BD and SS and all authors read and approved the final manuscript.

\section{Competing interests}

The authors declare that they have no competing interests.

Received: 28 April 2011 Accepted: 22 December 2011 Published: 22 December 2011 


\section{References}

1. Kotigadde S, Ballal M, Jyothiriatha, Kumar A, Rao S, Shivananda PG: Mycotic keratitis: A study in coastal Karnataka. Indian J Ophthamol 1992, 40:31-33.

2. Bharathi MJ, Ramakrishnan R, Vasu S, Meenakshi R, Palaniappan R:

Epidemiological characteristics and laboratory diagnosis of fungal keratitis. A three-year study. Indian J Ophthalmol 2003, 51:315-321.

3. Srinivasan M, Gonzales CA, George C, Cevallos V: Epidemiology and etiological diagnosis of corneal ulceration in Madurai, South India. $\mathrm{Br} J$ Ophthalmol 1997, 81:965-971.

4. Chander J, Sharma A: Prevalence of fungal corneal ulcers in Northern India. Infection 1994, 22:207-209.

5. Gopinathan U, Garg P, Sharma S, Rao GN: Review of epidemiological features microbiological diagnosis and treatment outcome of microbial keratitis: Experience over a decade. Indian J Ophthalmol 2009, 57:273-279.

6. Desphande DS, Koppikar GV: A study of mycotic keratitis in Mumbai. Indian J Pathol Microbiol 1999, 42:81-87.

7. Saha S, Banerjee D, Khetan A, Sengupta J: Epidemiological profile of fungal keratitis in urban population of West Bengal India. Oman J Ophthamol 2009, 2:114-118.

8. Basak KS, Basak S, Mohanta A, Bhowmick A: Epidemiological and microbiological diagnosis of suppurative keratitis in Gangetic West Bengal, Eastern India. Indian J Ophthalmol 2005, 53:17-22.

9. Satpathy G, Vishalakshi P: Ulcerative keratitis: microbial keratitis and sensitivity pattern-a five year study. Ann Ophthalmol 1995, 27:301-306.

10. Sharma S, Kunimoto DY, Gopinanthan U, Athmanathan S, Garg P, Rao GN: Evaluation of corneal scraping smear examination methods in the Diagnosis of bacterial and fungal keratitis. Cornea 2002, 21:643-647.

11. Zhang W, Yang $H$, Jiang L, Han L, Wang L: Use of potassium hydroxide, Giemsa and calcofluor white staining techniques in the microscopic evaluation of cornea Scrapings for diagnosis of fungal keratitis. J Int Med Res 2010, 38:1961-1967.

12. Panda T, Pani PK, Mishra N, Mohanty RB: A comparative account of diversity and distribution of fungi in tropical forest soils and sand dunes of Orissa, India. J Biodiversity 2010, 1:27-41.

13. Krishnan T, Sengupta S, Reddy PR, Ravindran RD: Secondary Pseudomonas infection of fungal keratitis following use of contaminated natamycin eye drops: a case series. Eye 2009, 23:477-479.

14. Jhanji V, Sharma N, Mannan R, Titiyal JS, Vajpayee RB: Management of tunnel infection with voriconazole. J Catarac Refract Surg 2007, 33:915-917.

\section{Pre-publication history}

The pre-publication history for this paper can be accessed here: http://www.biomedcentral.com/1471-2415/11/39/prepub

doi:10.1186/1471-2415-11-39

Cite this article as: Rautaraya et al:: Diagnosis and Treatment Outcome of Mycotic Keratitis at a Tertiary Eye Care Center in Eastern India. BMC Ophthalmology 2011 11:39.

\section{Submit your next manuscript to BioMed Central and take full advantage of:}

- Convenient online submission

- Thorough peer review

- No space constraints or color figure charges

- Immediate publication on acceptance

- Inclusion in PubMed, CAS, Scopus and Google Scholar

- Research which is freely available for redistribution

Submit your manuscript at www.biomedcentral.com/submit
Biomed Central 